\title{
As Abordagens Policiais e o Caso Miranda v. Arizona (1966): violência institucional e o papel das cortes constitucionais na garantia da assistência do defensor na fase policial
}

Police frisk/search and the Miranda v. Arizona (1966) case: institutional violence and the role of Constitutional Courts in assuring right to counsel during police investigation

\author{
Gabriela Ponte Carvalho ${ }^{1}$ \\ Brasília/DF \\ caprilp@gmail.com \\ http://lattes.cnpq.br/9685042541440691 \\ http://orcid.org/0000-0002-7162-9100 \\ Evandro Piza Duarte ${ }^{2}$ \\ Universidade de Brasília - Brasília/DF \\ evandropiza@gmail.com \\ http://lattes.cnpq.br/5003630503816604 \\ http://orcid.org/0000-0002-0077-0297
}

\begin{abstract}
Resumo: O texto analisa a doutrina construída a respeito dos direitos do acusado nos Estados Unidos, a partir da decisão da Suprema Corte no caso Miranda v. Arizona (1966). Descreve-se o modo como o direito de não produzir prova contra si (nemo tenetur se detegere) se manifesta na fase de policiamento, identificação de suspeitos e investigação policial. Pretende-se, com isso, demonstrar as diferenças entre o direito estadunidense e o direito brasileiro, realçando, neste caso, o caráter essencialmente formal das interpretações que visam a garantir direitos
\end{abstract}

1 Graduada em Direito pela Universidade de Brasília (UnB). Advogada.

2 Professor de Direito Processual Penal e Criminologia na Faculdade de Direito da Universidade de Brasília (UnB). Mestre em Direito pela UFSC e Doutor em Direito pela UnB. 
aos suspeitos. Desse modo, intenta-se demonstrar a responsabilidade pela violência institucional presente em decisões do Supremo Tribunal Federal, que, ao contrário da Suprema Corte dos Estados Unidos, não se defronta com as dimensões práticas e constitucionais da custódia de suspeitos e das confissões feitas na fase policial.

Palavras-chave: Direitos Fundamentais; Direito ao Silêncio; Direitos do Acusado; Processo Penal; Miranda v. Arizona; Suspeito.

ABSTRACT: This study analyzes the doctrine about the rights of the accused in the United States of America, through an examination of the Miranda v. Arizona case. It explores how the privilege against self-incrimination is applied in the phase of police investigation. Thus, it is intended to demonstrate the differences between the American and the Brazilian laws, highlighting, in the latter, the formality in the implementation of such rights. Such a formality indicates the responsibility for allowing institutional violence that lies in the decisions of the Brazilian Supreme Court, which, unlike the American Court, does not cope with the practical and constitutional aspects of the custody of suspects and the confessions obtained during a police investigation.

KEYWORDS: Fundamental rights; right to remain silent; rights of the accused; criminal procedure; Miranda v. Arizona; suspect.

SuMÁRIo: Introdução; 1. O Caso Miranda v. Arizona: O debate entre duas tradições de investigação; 2. O Paradoxo da imposição de limites à violência policial: o aviso de Miranda como instrumento de eficácia processual e melhoria das práticas de investigação; 3. Miranda v. Arizona em perspectiva; 4. O Direito ao Silêncio no sistema jurídico brasileiro: o imponderável valor jurídico conferido às confissões obtidas na fase policial sem a presença do advogado; Conclusão.

\section{INTRODUÇÃo}

A comparação entre as práticas judiciais dos EUA e do Brasil oferece pistas sobre semelhanças e diferenças quanto ao modo de construção da cidadania (LIMA, 1989) $)^{3}$. Especificamente, quando se comparam os

3 Brandâo, ao comparar o aumento da participação do Judiciário nas duas sociedades, considera, com otimismo, que a sociedade americana seria, desde 
debates da Suprema Corte dos EUA com os padrões brasileiros, doutrinários e jurisprudenciais de solução de conflitos penais, um aspecto salta aos olhos: a diferença entre os sistemas de garantias constitucionais para lidar com suspeitos. Ao contrário dos tribunais brasileiros, os americanos judicializaram as situações de suspeita e, obviamente, com ela, os procedimentos das forças policiais que são adotados na atividade de policiamento. Essa judicialização significa, na prática, a constitucionalização da investigação e a tendência de limitação dos poderes da polícia ou, no mínimo, denota a preocupação do Poder Judiciário com a qualidade da justiça presente no cotidiano dos cidadãos daquele país. ${ }^{4}$

A atuação cotidiana da Polícia não é esquecida pela Suprema Corte dos EUA, sob o pretexto de que se trata de matéria de fato. Ao invés disso, a dimensão cotidiana e prática dos direitos dos cidadãos durante as abordagens policiais é objeto de intenso debate judicial. Um exemplo extremo desse aspecto é abordado neste texto. Trata-se da relação entre o direito ao silêncio, o direito de não produzir prova contra si, o direito à assistência de um advogado e o valor jurídico atribuído às confissões obtidas mediante erro, fraude ou coação na fase policial.

As questões propostas são as seguintes: confissões e depoimentos feitos diretamente aos policiais e sem a presença de um advogado podem ser considerados válidos? E, em caso afirmativo, sob quais condições podem ser aceitos?

O caso Miranda v. Arizona, ponto de partida para o debate ora travado, tornou-se uma das mais influentes decisões da Suprema Corte dos EUA. O processo confrontou duas fortes linhas de argumentação quanto aos direitos do cidadão: uma que validava e outra que combatia as práticas tradicionais de abordagem e investigação policial. A apresentação concisa dos fatos que levaram ao início da investigação, assim como daqueles que permitiram a elevação do caso até a Suprema Corte

os anos de 1960, uma "democracia de direitos", capaz de vincular os três poderes a esse ideal (2015, p. 1444).

4 A comparação proposta pretende elucidar qual o papel do Poder Judiciário no controle da violência policial e do impacto dessa na construção da culpabilidade. Não são considerados os aspectos referentes ao hipercarceramento decorrente, inclusive, de medidas de relativização interpretativa dos próprios julgados aqui tratados. 
e a exposição dos argumentos utilizados pelos defensores de ambos os pontos de vista fornecem as linhas gerais para a comparação com os padrões adotados no Brasil. ${ }^{5}$

\section{O Caso Miranda v. Arizona: O debate entre duas TRADIÇÕES DE INVESTIGAÇÃO}

Em março de 1963, Ernesto Miranda foi preso em casa e levado a uma delegacia na cidade de Phoenix, Arizona (Miranda v. Arizona, 384 U.S. 436, 1966). Uma investigação policial o apontara como suspeito de um crime de sequestro seguido de estupro cometido alguns dias antes. $\mathrm{Na}$ delegacia, a vítima o reconheceu como autor do crime (RILEY, 1994, p. 41 e 42). Levado a uma sala de interrogatório, o suspeito foi interrogado por duas horas, escrevendo e assinando, ao final, termo de confissão. Nele constava um parágrafo digitado, em que reconhecia ter confessado voluntariamente, sem ameaças ou promessas de impunidade, com perfeito conhecimento de seus direitos e compreensão de que o que afirmasse poderia ser usado em seu desfavor ${ }^{6}$ (RILEY, 1994, p. 42). Na ocasião, Miranda confessou ter realizado um roubo, e foi por isso condenado à pena de 20 a 25 anos (RILEY, 1994, p. 56 e 63). No julgamento do sequestro e estupro, perante o júri, a confissão foi utilizada como prova, apesar dos protestos do advogado do réu, que requereu o reconhecimento da inconstitucionalidade da forma como a confissão foi obtida. Ernesto Miranda foi condenado por sequestro, estupro e roubo, devendo cumprir não menos que 40 anos e não mais que 55 anos de prisão (RILEY, 1994, p. 63).

$\mathrm{Na}$ fase recursal, a Suprema Corte do Arizona manteve a condenação, considerando não ter ocorrido lesão aos direitos do réu no interrogatório, pois ele não pedira, especificamente, a assistência de advogado durante a investigação policial (Miranda v. Arizona, 384 U.S. 436, 1966).

5 A dimensão racial dos julgados dos anos 1960/1970 não foi explorada no presente texto, mas podem ser encontradas algumas referências em: WANDERLEY, 2017; DUARTE, QUEIROZ, GARCIA, 2016.

6 Nos termos originais: "I, __ do hereby swear that I make this statement voluntarily and of my own free will, with no threats, coercion, or promises of immunity, and with full knowledge of my legal rights, understanding any statement I make may be used against me.” 
No entanto, pelo depoimento oferecido em juízo pelos policiais, verificouse que o réu não fora alertado de seus direitos durante o interrogatório, mormente o de consultar um advogado antes de se submeter às perguntas, e de tê-lo presente durante os atos do interrogatório (RILEY, 1994, p. 57 e 58). Os policiais afirmaram ter presumido que o réu conhecesse seus direitos, pois já havia sido preso anteriormente (RILEY, 1994, p. 45). O réu chegou a dizer que, quando os policiais o buscaram em sua casa, não sabia se tinha escolha entre acompanhá-los ou não, e que, ao perguntar sobre a razão de sua prisão, recebeu a resposta pouco elucidativa de que não lhe podiam dizer nada (RILEY, 1994, p. 40 e 41).

O caso Miranda v. Arizona foi julgado em 1966 em decorrência de um pedido formulado pelo próprio réu para que se realizasse a revisão do julgamento do seu caso (RILEY, 1994, p. 70 e 72). Na ocasião, foram julgados três ${ }^{7}$ outros casos de confissões obtidas de forma semelhante e utilizadas como meio de prova para a condenação.

Da decisão desses casos nasce o conhecido Aviso de Miranda. Ele consiste na obrigação do Estado, na qualidade de Polícia, de esclarecer o suspeito no momento de sua prisão quanto ao seu direito de ficar em silêncio e de obter a assistência de um advogado. Desse modo, cria um padrão para a valoração judicial de confissões obtidas em circunstâncias semelhantes, capaz de determinar se a confissão produziu prova ilícita e, portanto, deve ser excluída do processo, ou, ao contrário, deve ser aceita como prova.

A posição da maioria dos juízes da Suprema Corte foi expressa pelo voto do Juiz Warren, para quem o caso propunha questões estruturais da Jurisprudência criminal americana, pois abordava a determinação de limites à liberdade pessoal em uma investigação criminal que fossem aceitáveis e condizentes com a Constituição (Miranda v. Arizona, 384 U.S. 436, 1966).

O tema poderia ser tratado a partir da Quinta ou da Sexta Emendas Constitucionais dos Estados Unidos. Dispõe a Quinta Emenda que

7 Em cada um deles (Miranda v. Arizona, Vignera v. New York, Westover v. United States e California v. Stewart), o réu fora interrogado por policiais, detetives ou acusadores, quando estava sob custódia da polícia, em sala onde não tinha nem poderia ter contato com outras pessoas (Miranda v. Arizona, 384 U.S. 436, 1966). Além disso, nenhum dos réus fora avisado de seus direitos durante o processo de interrogatório. 
"ninguém poderá pelo mesmo crime ser duas vezes ameaçado em sua vida ou saúde; nem ser obrigado em qualquer processo criminal a servir de testemunha contra si mesmo; nem será privado de sua vida, liberdade ou propriedade sem o devido processo legal"». A Sexta Emenda, por sua vez, garante que o acusado em processo criminal tenha direito à assistência de um advogado em sua defesa ${ }^{9}$. A defesa de Miranda optou por alegar violação à Sexta Emenda, ou seja, a nulidade da confissão de Miranda decorreria do fato de que não se lhe tinha sido facultado acompanhamento de advogado no interrogatório (RILEY, 1994, p. 50). Contudo, a discussão e o julgamento concentraram-se na aplicação da Quinta Emenda, ou seja, no direito do réu de não se auto-incriminar, mas, como se verá adiante, retomaram o tema da assistência de um advogado.

No voto majoritário, faz-se extensa referência ao caso Escobedo v. Illinois, julgado em 1964 (378 U.S. 478). Nesse caso, o interrogatório se dera na delegacia, sem que o réu tivesse sido cientificado de seus direitos de permanecer em silêncio, de consultar advogado e de tê-lo presente durante o procedimento. Apesar disso, o réu especificamente pedira a presença de seu advogado, o que lhe fora negado. Algemado e de pé, o acusado fora interrogado por quatro horas, até que confessasse. A confissão foi depois utilizada, em sessão de julgamento, como prova de culpa (Escobedo v. Illinois, 378 U.S. 478, 1964). Na ocasião a Suprema

8 A tradução literal da referida Emenda é: "Ninguém será detido para responder por crime capital, ou outro crime infamante, salvo por denúncia ou acusação perante um Grande Júri, exceto em tratando de casos que, em tempo de guerra ou de perigo público, ocorram nas forças de terra ou mar, ou na milícia, durante serviço ativo; ninguém poderá pelo mesmo crime ser duas vezes ameaçado em sua vida ou saúde; nem ser obrigado em qualquer processo criminal a servir de testemunha contra si mesmo; nem ser privado da vida, liberdade, ou bens, sem processo legal; nem a propriedade privada poderá ser expropriada para uso público, sem justa indenização.” A expressão destacada foi: "No person [...] shall be compelled in any criminal case to be a witness against himself, nor be deprived of life, liberty, or property, without due process of law". Observe-se que o termo "be a witness" pode adquirir também o sentido de "não produzir prova contra si mesmo", já que no caso Boyd v. United States, de 1886, um dos primeiros casos a respeito da Quinta Emenda, no qual se debatia a legalidade de um mandado de exibição de documentos, já era feita tal interpretação extensiva do dispositivo (BOYD V. United States, 1886).

9 No original: "In all criminal prosecutions, the accused shall enjoy the right [...] to have the assistance of counsel for his defense". 
Corte conclui que afirmações feitas pelo réu em tais circunstâncias não eram admissíveis constitucionalmente. Isso porque o direito de receber assistência jurídica deveria ser garantido mesmo antes da fase processual da investigação, desde que a investigação policial já se concentrasse em um suspeito específico (Escobedo v. Illinois, 378 U.S. 478, 1964).

Os princípios discutidos nessa decisão foram reafirmados no julgamento de Miranda. A maioria concluiu que nenhuma declaração feita em interrogatório sob custódia, seja no sentido de confessar ou de negar autoria do crime, pode ser usada pela acusação, salvo ante a comprovação de terem sido plenamente assegurados os direitos constitucionais do acusado. Por sua vez, definiu-se a custódia como qualquer limitação ou prejuízo significativo à liberdade do acusado (Miranda v. Arizona, 384 U.S. 436, 1966).

Logo, para que se possa utilizar em juízo as informações obtidas por meio de interrogatório, o acusado deve ser informado de que tem o direito a permanecer em silêncio, que qualquer declaração poderá ser usada como prova contra ele mesmo, e que tem o direito à presença de um advogado. Na ausência de condições de pagar por um defensor, deve ser informado de que o Estado deve designar quem o defenda ${ }^{10}$ (Miranda v. Arizona, 384 U.S. 436, 1966).

Entretanto, quatro dos nove juízes da Suprema Corte (Clark, Harlan, Stewart e White) opinaram contrariamente à decisão expressa pelo Juiz Warren, em graus variados, o que demonstra como o tema era controverso, inclusive na opinião pública estadunidense (Miranda v. Arizona, 384 U.S. 436, 1966).

O juiz Clark defendeu que a violência policial era excepcional, logo não justificaria a mudança nos procedimentos policiais. Por sua vez, a decisão em Escobedo v. Illinois (378 U.S. 478, 1964) não imporia

10 Observe-se que no sistema estadunidense o acusado pode abrir mão desses direitos, mas deve fazê-lo de forma consciente e voluntária. Não se admite a presunção de que todos os cidadãos conhecem seus direitos. Se o réu abrir mão do direito ao silêncio, incumbe à acusação provar que o réu tinha ciência de seus direitos. Se, da mesma forma, após não recorrer ao direito ao silêncio ou à presença de advogado, o acusado mudar de ideia, o interrogatório deve cessar ou ser suspendido até que se resolva a pendência (Miranda v. Arizona, 384 U.S. 436, 1966). 
a renúncia expressa dos direitos, nem obrigava a acusação a provar que essa renúncia tivesse sido livre e consciente. Pelo contrário, o reconhecimento da regularidade e legitimidade da confissão deveria buscar-se no conjunto de circunstâncias em que se tivesse realizado, não pelo cumprimento de normas procedimentais específicas (Miranda v. Arizona, 384 U.S. 436, 1966).

O juiz Harlan, por sua vez, ressaltou a ineficácia desse tipo de procedimento para os poucos policiais que ainda utilizavam as táticas do third degree ${ }^{11}$, pois o policial disposto a extorquir uma confissão de um suspeito certamente estaria disposto a mentir a respeito do aviso de Miranda. Desse modo, o objetivo da decisão da Corte não seria proteger cidadãos contra a violência policial, mas livrar o acusado de qualquer tipo de pressão e desencorajar qualquer confissão. Todavia, em seu ponto de vista, esse não era o objetivo da emenda constitucional que não proibiria a pressão leve, natural do ambiente policial, muito embora não defina como se poderia mensurar o grau de coação legítima no interrogatório. Argumentou que seriam indiscutíveis as diferenças entre a fase policial da investigação e a fase processual quanto aos direitos do acusado, não incidindo naquela a Quinta e Sexta Emendas, pois o próprio texto deixaria clara a necessidade de um processo para a aplicação dos direitos nelas prescritos (Miranda v. Arizona, 384 U.S. 436, 1966).

O juiz White, no mesmo sentido, entendia que a decisão não encontrava suporte no desenvolvimento histórico do princípio ou no texto da Emenda invocada. A questão da validade das confissões, antes, era decidida com base em normas infraconstitucionais. A ausência de induzimento, ameaça ou promessa no interrogatório era suficiente para que se considerassem as declarações do acusado voluntárias. Nesse contexto, a situação de custódia seria um aspecto insuficiente para sustentar a presunção de coerção. Se outras circunstâncias indicassem que o preso se manifestou voluntariamente, não haveria motivo para excluir suas declarações dos autos. O aviso, portanto, não seria necessário. Em definitiva, o custo do interrogatório não seria tão alto, considerando-se os seus benefícios (Miranda v. Arizona, 384 U.S. 436, 1966).

11 Definida por Richard A. Leo (2004, p. 39) como "a imposição de sofrimento físico ou mental para obter informação” (tradução livre). 
Como se percebe, a minoria compunha-se de juízes que atribuíam grande valor à confissão e viam no interrogatório um meio de prova indispensável para a condenação criminal. À época, não apenas nos Estados Unidos, mas também no Brasil, essa perspectiva era comum. ${ }^{12}$ De igual modo, havia aqueles que consideravam impossível avalizar o trabalho policial sem revolver a matéria de fato em cada caso ou, ainda, aqueles que consideravam que na fase inquisitória não se poderia usar todos os parâmetros constitucionais de garantia, pois ainda não haveria processo.

Entretanto, o caminho para a decisão do caso esmiuçou o tema dos procedimentos policiais ilegais e de sua eficiência na resolução de casos criminais, utilizando de estudos empíricos e "CPIs" sobre a atuação da polícia. A Wickersham Commission ${ }^{13}$, reunida na década de 1930 , foi extensamente citada no julgamento. A Corte reconheceu que a violência policial não ocorria apenas em alguns casos singulares e excepcionais, mas, ao contrário, era um padrão comum existente nas polícias estadunidenses. E, ao mesmo tempo, reconheceu que a Suprema Corte não poderia dar um aval generalizado a essas práticas de violação de direitos que, de fato, já eram conhecidas da sociedade americana.

Dessa forma, o voto majoritário reafirmou as conclusões do Wickersham Commission Report que considerara insuficiente "alcançar a justiça obtendo um resultado adequado através de meios irregulares"14 (SANKEY, 1931, apud Miranda v. Arizona, 384 U.S. 436, 1966). Logo, prevaleceu o entendimento de que a facilitação da confissão era um elemento decisivo na consolidação da ineficiência policial quanto à descoberta de outras provas. Nesse contexto, o voto vencedor pontuou quais eram as práticas usadas pela Polícia no interrogatório que se opunham à Constituição.

12 No contexto americano, o Wickersham Commission Report e os argumentos dos próprios juízes da Corte apresentados adiante corroboram a descrição. No contexto brasileiro, a valorização da confissão como meio de prova decorre de nossa tradição inquisitória, veja-se: CARVALHO, 2005, p. 229-252.

13 Comissão estabelecida pelo presidente Herbert Hoover, com o intuito de identificar as causas da criminalidade no país, e para fazer recomendações e sugestões para a formação de políticas públicas mais apropriadas.

14 Tradução livre de: "It is not sufficient to do justice by obtaining a proper result by irregular or improper means". 
Em ambiente dominado por policiais, o investigado não se sente confiante, mas amedrontado, logo o interrogador tira vantagem dessa situação. O interrogador age como se já soubesse que o acusado é realmente culpado, e toma essa culpa como um fato. A polícia chegava a recorrer a testemunhos falsos de reconhecimento do acusado ou a falsas vítimas para o associarem a outros crimes, compelindo-o a confessar as acusações do caso investigado, para se livrar das outras. As perguntas se dirigiam ao motivo e a outros aspectos semelhantes, não à autoria em si. Enfraquecida, assim, a pretensão de negar as acusações, restava ao acusado apenas confirmar a versão pré-concebida pela polícia (Miranda v. Arizona, 384 U.S. 436, 1966) $)^{15}$.

Após obter a admissão inicial da culpa amenizada, o interrogador passava a perguntas tendentes a invalidar a tese da atenuante ou da excludente de ilicitude, em busca de uma condenação pela conduta mais grave. Quando o acusado se recusava a falar, os policiais eram instruídos a conceder o direito ao silêncio, mas alertando-o de que isso seria utilizado em seu desfavor e afirmando que, se não fosse culpado, nada teria a esconder (Miranda v. Arizona, 384 U.S. 436, 1966).

É preciso destacar: a Suprema Corte reconheceu um padrão geral de atuação da polícia. Em nenhum dos casos julgados em Miranda v. Arizona houve indícios de que as declarações dos suspeitos tinham sido involuntárias. No entanto, os suspeitos estavam inseridos em ambiente hostil, predominantemente policial, privados de contato com o exterior e foram questionados de forma ameaçadora pela polícia. Também não foram alertados sobre seus direitos. Logo, não se poderia presumir que houvessem desistido conscientemente (Miranda v. Arizona, 384 U.S. 436, 1966).

Eis aqui o ponto mais relevante da análise elaborada pela Suprema Corte dos EUA: conhecidas as práticas policiais, por meio de relatos

15 Observou-se ainda que o investigador simulava amenizar a gravidade moral do crime, culpando a vítima ou a sociedade. Tudo isso poderia levar o investigado a confessar, acreditando não ter como negar a autoria e pensando que o crime imputado não teria sido, afinal, tão grave. Quando essas táticas não apresentavam resultado, a insistência e a atmosfera do local assumiam grande importância. O interrogatório podia durar vários dias, tendo-se registrado casos de privação de comida, água e sono (Miranda v. Arizona, 384 U.S. 436, 1966). 
científicos e comissões de investigação, ainda que elas não sejam as práticas de todos os distritos policiais, pode-se antever um padrão social no qual os interrogatórios são realizados. Os dados da realidade falam mais alto e não precisam ser trazidos para um processo singular no qual se acusa um policial de tortura ou coação, mas podem ser aduzidos pelos conhecimentos recebidos de diversas instâncias políticas e científicas sobre as práticas policiais.

Entretanto, apesar de reconhecer que o ambiente policial não é favorável ao acusado, a Corte não se alinhou à tese de que qualquer confissão feita sob custódia deveria ser considerada inconstitucional, pois quando realmente voluntária, livre de qualquer tipo de induzimento, a confissão poderia ser válida e útil em juízo. Logo, tratava-se de sublinhar quais deveriam ser os comportamentos, na prática, esperados das instituições policiais e judiciárias. Aqui, a solução prática foi inverter o ônus da prova para quem, de fato, tem a possibilidade de produzi-la. Uma vez sob custódia, o réu não pode provar que foi torturado ou coagido. Quem tem o dever de provar a ausência de coação é aquele em posição de poder: o próprio Estado.

\section{O Paradoxo da IMPOSIÇÃo de limites À VIOlÊNCIA POLICIAL: o Aviso de Miranda como instrumento de eficácia PROCESSUAL E MELHORIA DAS PRÁTICAS DE INVESTIGAÇÃO}

Para a Suprema Corte dos EUA, em um sistema jurídico que preza pelas garantias constitucionais dos acusados, o ônus da prova da culpa pertence ao Estado, que dele deve se desincumbir sem recorrer à força. Tendo em vista que o direito à não autoincriminação tem estreita conexão com a dignidade humana, não seria razoável aplicá-lo somente à fase processual. Se assim não fosse, todos os direitos do acusado estariam em risco, pois o próprio processo já estaria eivado, desde o início, pelo vício de uma confissão que contaminaria as demais provas.

A percepção da Suprema Corte dos EUA conduz a uma conclusão cristalina: se o Poder Judiciário não pretende fiscalizar de modo efetivo a fase policial, ele, de fato, renuncia a dar eficácia aos direitos fundamentais. Isso porque, quando alguns direitos têm eficácia eventual, em hipóteses raras, eles se tornam direitos de segunda categoria ou não-direitos. De 
igual modo, o reconhecimento de direitos fundamentais apenas na fase processual poderia conferir ao legislador a possibilidade de afastar a aplicação da Constituição na medida em que definisse o que pertence a uma ou a outra fase, tornando o sistema de garantias inútil. Se a prova colhida numa fase, sem o escrutínio constitucional, é utilizada para tomar decisões interlocutórias ou para fundamentar a condenação, há evidente risco de esvaziamento da força normativa do rol de garantias.

Portanto, a Suprema Corte dos EUA declarou que o direito assegurado pela Quinta Emenda existia também na fase pré-processual, de investigação, ou seja, o direito ao silêncio deveria limitar também o trabalho da Polícia. De igual modo, afastou a distinção entre declaração que configure confissão total da acusação e admissões parciais de culpa. O direito de não ser testemunha contra si mesmo é amplo e absoluto, abrange todo e qualquer nível de culpabilidade, inclusive a negativa de culpa. Logo, a acusação não poderia fazer uso nem mesmo de alegações de inocência (Miranda v. Arizona, 384 U.S. 436, 1966).

$\mathrm{O}$ acusado, além de ser avisado do direito a permanecer em silêncio, deveria receber a informação de que suas declarações podem ser usadas contra ele, deixando evidenciado que ele está cercado por pessoas empenhadas em sua incriminação, pois desse modo ele pode tomar as cautelas devidas em suas declarações, caso decida fazer alguma coisa (Miranda v. Arizona, 384 U.S. 436, 1966). A garantia do direito à presença do advogado ${ }^{16}$ durante o interrogatório reduziria significativamente os riscos de irregularidades nesse procedimento.

Eis aqui um segundo aspecto relevante da decisão: a Suprema Corte preocupava-se com a dimensão material e concreta dos direitos dos investigados, superando uma visão formalista. $\mathrm{Na}$ fase policial o direito à não autoincriminação somente poderia ser garantido com a presença efetiva do advogado. Logo, não bastaria a possibilidade de assistência, de o investigado se comunicar, caso tivesse, com defensor. Trata-se da garantia efetiva presença do defensor quando o investigado está diante da polícia.

16 E a simples omissão do acusado quanto ao pedido não poderia equiparar-se à desistência. A renúncia só se caracterizaria quando expressa e posterior à ciência do direito. No entender do Tribunal, quem desconhece esse direito e, exatamente por isso, não o exerce é certamente quem dele mais necessita (Miranda v. Arizona, 384 U.S. 436, 1966). 
O salto qualitativo produzido pelo pragmatismo da Suprema Corte Norte-Americana é evidente. Segundo a Corte, a experiência, resultante da percepção cotidiana e científica do conjunto das práticas policiais e jurídicas, justificava a tese de que a manifestação de vontade dos investigados somente estaria livremente garantida com a presença do defensor, pois este representaria um contrapeso ao poder de direito e de fato que a polícia possui e à situação de desvantagem concreta que esse poder provoca.

Por sua vez, nada, absolutamente nada, poderia substituir o aviso de Miranda, nem mesmo a experiência anterior do acusado com os procedimentos policiais. A partir do instante em que o acusado manifestasse interesse em receber assistência de advogado, nenhuma outra pergunta lhe poderia ser dirigida até a satisfação desse direito. Qualquer declaração feita em condição diversa deveria ser considerada resultado de coação, ainda que sutil (Miranda v. Arizona, 384 U.S. 436, 1966).

Nesse contexto, a Suprema Corte dos EUA redefiniu a oposição presente no senso comum entre os Interesses da Sociedade (representada pela Polícia) em prender criminosos e os Direitos dos Acusados. Ela não corroborou o argumento segundo o qual deveria haver a prevalência daqueles, diante da utilidade e da necessidade do interrogatório, ou melhor, diante da necessidade de validar todo e qualquer trabalho policial, atribuindo presunção de legitimidade à atuação da Polícia. Ao invés disso, a Corte ${ }^{17}$ seguiu outra direção.

Portanto, segundo a Corte, as limitações ao interrogatório não deveriam ser vistas como obstáculos à atuação da polícia ou meios de dificultar a condenação de criminosos. Logo, a confissão sem a presença do defensor não era, de fato, imprescindível para a condenação (Miranda v. Arizona, 384 U.S. 436, 1966).

Em vez de considerar os direitos fundamentais como obstáculos à atuação da Polícia, a Suprema Corte dos EUA concluiu que a invalidação de provas duvidosas deveria ter um efeito de aprimorar o trabalho policial.

17 Ela reprisou as afirmações de J. Edgar Hoover (1952), antigo diretor do FBI, segundo quem: "A aplicação da lei, no entanto, ao derrotar o criminoso, deve manter invioladas as liberdades históricas do indivíduo. Prender o criminoso, mas, ao fazê-lo, destruir a dignidade do indivíduo, seria uma vitória vazia” (em tradução dos autores). 
Portanto, assumiu uma postura constitucional, segundo a qual a Corte tem a obrigação de contribuir e sinalizar para o aprimoramento das práticas policiais, em vez de, simplesmente, desconsiderar os abusos cotidianos.

\section{Miranda v. Arizona em perspectiva}

Em síntese, a decisão da Suprema Corte dos EUA em Miranda v. Arizona (384 U.S. 436, 1966) conclui que: (i) a acusação não pode se valer de quaisquer declarações obtidas por meio de interrogatório, a não ser que demonstre que o acusado teve todos os seus direitos constitucionais devidamente assegurados (p. 444-491); (ii) o ambiente policial naturalmente intimida o acusado e cabe ao Estado adotar medidas para que isso não o prejudique injustamente (p. 445-458); (iii) essas medidas consistem em avisá-lo de todos os seus direitos (p. 467-473); (iv) a vontade do acusado de permanecer em silêncio ou de consultar um advogado pode ser manifestada a qualquer momento, e deve ser plenamente respeitada (p. 473-474); (v) a melhor forma de garantir ao acusado sua capacidade de entendimentos sobre seus direitos é garantir-lhe a presença efetiva do advogado no interrogatório (p. 473-474); (vi) se não há advogado presente durante o interrogatório, incumbe à acusação provar, com os meios que lhe forem possíveis, que o acusado renunciou aos seus direitos de forma consciente; (p. 475) (vii) a garantia de todos esses direitos não traria prejuízos à investigação e à aplicação da lei penal (p. 479-491).

Houve divergências posteriores sobre o alcance do Aviso de Miranda.

Em 1976, julgou-se o caso Beckwith v. United States 425 U.S. 341. Nessa ocasião, definiu-se que entrevistas ou questionamentos realizados pelo Internal Revenue Service na investigação de irregularidades fiscais só deveriam ser obrigatoriamente precedidas pelo Aviso de Miranda se o interrogado estivesse sob custódia, ou seja, se houvesse privação de liberdade (Beckwith v. United States, 425 U.S. 341, 1976).

Em situação polêmica, onde se debatia a legitimidade dos métodos de investigação, em Oregon v. Mathiason 429 U.S. 492 ${ }^{18}$ (1977),

18 No caso, o policial ao investigar um roubo, após tentar contato por várias vezes com um suspeito, deixou um cartão de visitas em seu apartamento, 
decidiu-se que a Polícia não é obrigada a fornecer o Aviso de Miranda a todos interrogados.

A Corte de Oregon considerou o quadro como de limitação de liberdade, pois o policial estava sozinho com o suspeito em local fechado e mentiu quanto à existência de provas, dando pouca importância ao fato de que o comparecimento foi voluntário, o suspeito sabia que não estava preso e deixou o local pouco tempo depois. A Suprema Corte dos EUA, por sua vez, considerou que a Corte do Estado de Oregon fizera leitura muito ampla da decisão de Miranda. Todavia, observe-se que, embora a decisão seja passível de críticas à luz dos fundamentos utilizados no Caso Miranda v. Arizona (384 U.S. 436, 1966), o argumento mais relevante foi, de fato, a ausência de uma situação concreta de restrição de direitos.

Entretanto, a Suprema Corte dos EUA, manteve-se alinhada a sua posição em Miranda v. Arizona (384 U.S. 436, 1966). Em 1976, por exemplo, julgou-se o caso Doyle v. Ohio (apud LEWIS, 1979, p. 387 e 388). O réu havia sido preso por vender maconha a um informante da polícia. Após o Aviso de Miranda, permanecera em silêncio. O preso forneceu declarações apenas no tribunal, ocasião em que afirmou que a prisão havia sido realizada por armação da polícia. O silêncio que o réu mantivera no momento da prisão foi interpretado como indício de culpa, e essa estratégia da acusação levou-o à condenação em primeira instância, o que foi posteriormente confirmado pela Corte de Ohio. A Suprema Corte dos EUA, porém, considerou o uso do silêncio do réu em seu desfavor como violação do princípio do devido processo legal.

Por sua vez, o impacto das decisões da Suprema Corte dos EUA sobre os tribunais inferiores é tema complexo e tem sido objeto de extensa pesquisa. Vários tribunais não aceitam automaticamente as interpretações da Corte. No caso em questão, contudo, a reação dos tribunais foi, em

alegando que havia algo para discutir e pedindo que mantivesse contato telefônico. O suspeito compareceu voluntariamente ao posto policial, onde foi interrogado, após ter sido alertado de que não estava preso. O policial afirmou acreditar que ele estava envolvido no roubo, mas mentiu ao alegar que haviam sido encontradas digitais no local. O suspeito confessou o crime apenas alguns minutos após a sua chegada. Porém, somente depois recebeu o aviso de Miranda e gravou em fita sua confissão, tendo sido liberado (Oregon v. Mathiason 429 U.S. 492, 1977). 
geral, favorável. Donald Songer e Reginald Sheehan (1990) avaliaram 250 casos julgados por Cortes estaduais nos cinco anos subsequentes à decisão de Miranda ( 50 casos por ano) e verificaram que, apesar das controvérsias que a permearam, ela foi bem aceita. De todos os casos analisados, apenas em um não se observou o seu cumprimento, e em 12 esse cumprimento se deu de forma restrita. A quantidade de decisões em conformidade surpreende, ainda mais quando se consideram estudos anteriores, que sugeriam pouco alinhamento de tribunais inferiores com a interpretação. O mesmo estudo, no entanto, mostra que a porcentagem de decisões a favor do réu mudou pouco, no mesmo período analisado, de $21,4 \%$ a $21,8 \%$, o que sugere que, apesar de bem aceita, a decisão não alterou significativamente o número de condenações. Assim, por mais que a nova orientação tenha sido aplicada, não causou grandes alterações nos resultados (SONGER e SHEEHAN, 1990, p. 297-309).

Não obstante, a decisão Miranda v. Arizona (384 U.S. 436, 1966) foi de suma importância no desenvolvimento das regras do devido processo legal. O Aviso de Miranda, com todas as implicações que traz em relação aos direitos do acusado, especialmente quanto à declaração da ilicitude das provas obtidas inconstitucionalmente e sua exclusão do processo, foi uma decisão essencial nessa direção.

\section{O Direito ao Silêncio no sistema jurídico brasileiro: o IMPONDERÁVEL VALOR JURÍDICO CONFERIDO ÀS CONFISSÕES OBTIDAS NA FASE POLICIAL SEM A PRESENÇA DO ADVOGADO}

O Direito ao Silêncio sofreu várias transformações no direito brasileiro, correspondentes, sinteticamente, a duas fases, marcadas por uma série de disputas judiciais e doutrinárias. A primeira fase teve como característica principal a pacífica aplicação da redação original do Código de Processo Penal e durou até a promulgação da Constituição Federal de 1988. A menção ao direito do acusado de permanecer em silêncio já constava nos debates da jurisprudência brasileira anterior a 1988. Todavia, esse direito de calar não tinha a mesma extensão que tem hoje. Os direitos do acusado se limitavam a não obrigá-lo a prestar juramento antes de depor, a restringir as perguntas que lhe poderiam ser feitas e a proibir o uso da tortura (TROIS NETO, 2010, p. 94 e 95). 
As Constituições anteriores não faziam menção expressa ao direito ao silêncio. Logo, o réu deveria escolher entre fazer declarações possivelmente incriminadoras ou incoerentes, ou ter seu silêncio interpretado como indício de culpa.

Muito embora houvesse doutrinadores que afirmassem ser o interrogatório verdadeiro meio de defesa do réu (FRANCO, 1956, p. 260; FARIA, 1960, p. 283), a posição dos artigos referentes ao interrogatório no capítulo das provas, a postura inerte do advogado, sem a garantia do direito à conversa reservada e a perguntas, e a realização do ato no início do processo, sem o conhecimento da totalidade das provas, corroboravam um modelo de acusação inquisitorial para o qual o interrogatório deveria ser visto como meio de prova. Nesse contexto, ele tinha por finalidades: (i) permitir que o magistrado conhecesse a personalidade do acusado, (ii) conceder ao acusado a oportunidade de fazer conhecer sua versão dos fatos, e (iii) permitir ao juiz que analisasse as reações do acusado (ESPÍNDOLA, 1980, p. 25 e 26).

No entanto, a Constituição de 1988 estabeleceu novos direitos aos acusados, iniciando uma segunda fase de disputas judiciais, ao determinar em seu artigo $5^{\circ}$, LXIII, que “[o] preso será informado de seus direitos, entre os quais o de permanecer calado", o que era uma remissão direta à doutrina do Aviso de Miranda.

Porém, a interpretação dada a esse dispositivo tem sido distinta do cenário americano. Inicialmente, em 1998, no julgamento do RE 199.570/ MS, de relatoria do Ministro Marco Aurélio, foi declarada pelo Supremo Tribunal Federal a inconstitucionalidade da advertência judicial prevista no art. 186 do CPP, no sentido de que o silêncio poderia ser interpretado em desfavor do réu.

Logo, para o STF a parte final do art. 186 do CPP não havia sido recepcionada pela $\mathrm{CF} / 88$. Dessa forma, o acusado não poderia ser compelido a depor e seu silêncio não poderia levar o julgador a fazer um juízo negativo a seu respeito. Esse pensamento foi repetido em decisões posteriores ${ }^{19}$.

19 HC 80949, Relator(a): Min. Sepúlveda Pertence, Primeira Turma, julgado em 30/10/2001, DJ 14-12-2001; HC 91514, Relator(a): Min. Gilmar Mendes, Segunda Turma, julgado em 11/03/2008. 
As discussões judiciais deram motivo, a seguir, para a reforma do Código de Processo Penal de $2003^{20}$, que alterou o teor do mencionado artigo e lhe acrescentou um parágrafo único ("O silêncio, que não importará em confissão, não poderá ser interpretado em prejuízo da defesa”). Porém, manteve o art. 198, que determina: "O silêncio do acusado não importará confissão, mas poderá constituir elemento para a formação do convencimento do juiz". Por isso, apesar de a reforma não ter alterado ou revogado expressamente o artigo em pauta, deve-se considerar que ele não deve mais ser aplicado (SCARANCE FERNANDES, 2009, p. 19).

Todavia, permanece uma indefinição quanto à garantia efetiva desse direito, de modo muito semelhante ao debate estabelecido na Suprema Corte dos EUA nos anos de 1960.

Na doutrina, Aury Lopes Jr. afirma ser evidente a aplicação do direito ao silêncio ao acusado em liberdade. A Convenção Americana de Direitos Humanos, o Pacto de São José da Costa Rica, em seu art. 8, n. 2, "g", garante que toda pessoa tem o direito de não ser obrigada a depor contra si mesma, nem a confessar-se culpada, sem qualquer distinção entre pessoas presas ou em liberdade (2011, p. 624) ${ }^{21}$.

Por sua vez, o art. $6^{\circ}, \mathrm{V}$, do CPP, ao regulamentar a fase do inquérito, determina a oitiva do indiciado "com observância, no que for

20 A partir da Reforma de 2003, o direito ao silêncio está declarado não apenas na Constituição, mas também no Código de Processo Penal. A valoração negativa do silêncio do réu é violação ao princípio da presunção de inocência e aos princípios do contraditório e da ampla defesa. O interrogatório não é mais considerado meio de prova, mas, essencialmente, de defesa. É uma oportunidade para o réu, não um instrumento de que deve se valer a acusação. Se, porventura, o réu fizer declarações incriminadoras quando interrogado, a acusação poderá fazer uso dessas informações, mas isso não muda o fato de que o interrogatório é, em última análise, um direito do réu de defender-se. Assim, o interrogatório pode ser fonte de prova, mas não meio de prova (GRINOVER, GOMES FILHO e SCARANCE FERNANDES, 2010, p. 75).

21 Segundo a atual interpretação do STF, o Pacto de São José da Costa Rica não é equiparado a Emenda Constitucional por não ter sido aprovado nos termos do art. $5^{\circ}, \S 3^{\circ}$ da $\mathrm{CF} / 1988$. Entretanto, tem status de norma supralegal no Brasil, e o STF tem incorporado suas determinações em suas decisões, como se pode observar: RE 349703, Relator(a): Min. Carlos Britto, Tribunal Pleno, julgado em 03/12/2008, DJe-104; HC 87585, Relator(a): Min. Marco Aurélio, Tribunal Pleno, julgado em 03/12/2008, DJe-118; RE 466343, Relator(a): Min. Cezar Peluso, Tribunal Pleno, julgado em 03/12/2008, DJe-104. 
aplicável" das regras referentes ao interrogatório judicial. Bem se vê que a expressão não pode ser mais utilizada, após a Constituição de 1988, para relativizar direitos, pois não pode haver dois graus distintos de cidadania, conforme as fases da investigação ou do procedimento judicial. Não se pode aceitar que o legislador tivesse restringido, de forma implícita, direitos fundamentais. Nesse contexto, fica evidente que o interrogatório realizado por autoridade policial deve respeitar as garantias constitucionais e processuais do acusado.

Tanto o Pacto Internacional de Direitos Civis e Políticos ${ }^{22}$ como a Convenção Americana de Direitos Humanos ${ }^{23}$ mencionam o direito à assistência de um advogado e o dever do Estado de fornecer defensor aos hipossuficientes. Em nenhum dos textos se faz menção à existência do mesmo direito na fase policial, mas também não se faz menção expressa à fase processual, o que significa que esse direito pode ser garantido em todos os momentos da investigação (BOTTINO, 2009, p. 139).

No entanto, a aplicação de forma similar na fase de investigação do art. 185, referente à garantia da presença do defensor durante o interrogatório, tem sido debatida pelo STF sob a ótica anterior à Constituição de $1988^{24}$.

22 Art. 14, III, d: Toda pessoa acusada de um delito terá direito, em plena igualdade, a, pelo menos, as seguintes garantias: de estar presente no julgamento e de defender-se pessoalmente ou por intermédio de defender de sua escolha; de ser informado, caso não tenha defensor, do direito que lhe assiste de tê-lo e, sempre que o interesse da justiça assim exija, de ter um defensor designado "ex officio" gratuitamente, se não tiver meios para remunerá-lo.

23 Art. $8^{\circ}$, II, d, e: Toda pessoa acusada de um delito tem direito a que se presuma sua inocência, enquanto não for legalmente comprovada sua culpa. Durante o processo, toda pessoa tem direito, em plena igualdade, às seguintes garantias mínimas: direito do acusado de defender-se pessoalmente ou de ser assistido por um defensor de sua escolha e de comunicar-se, livremente e em particular, com seu defensor; direito irrenunciável de ser assistido por um defensor proporcionado pelo Estado, remunerado ou não, segundo a legislação interna, se o acusado não se defender ele próprio, nem nomear defensor dentro do prazo estabelecido pela lei.

24 Penal. Processual Penal. “Habeas corpus”. Deficiência da defesa. Irregularidade no inquérito policial. Interrogatório. Ausência de advogado. I. A deficiência da defesa só anulará o processo se houver prova de prejuízo para o réu. Súmula 523. II. Por se tratar de peça meramente informativa da denúncia ou da queixa, eventual irregularidade no inquérito policial não contamina o processo, nem enseja a sua anulação. III. A ausência de advogado no interrogatório do réu não vicia o ato, mesmo porque o defensor do acusado não 
O argumento de que o inquérito é apenas peça informativa, somado à conclusão de que qualquer irregularidade em seus procedimentos não deveria causar nulidade processual, esbarra na inserção no art. 155, em 2008, da autorização implícita para valoração pelo Juiz das informações colhidas no Inquérito. ${ }^{25}$ Logo, das duas, uma: ou se limitam as informações colhidas no Inquérito Policial apenas à função endoprocedimental de sustentar a denúncia, ou se aceitam as consequências da valoração como elemento de prova das informações ali colhidas, especialmente aquelas relativas ao controle da forma dos atos processuais, sobretudo quando a forma indica a limitação do arbítrio dos agentes do Estado. Ademais, a Reforma de 2003 modificou o teor do art. 187, IV que impedia o defensor de interferir no interrogatório. Essa proibição da participação do advogado não mais existe. Logo, o argumento de desnecessidade da presença do advogado no interrogatório policial não subsiste.

Neste contexto de despreocupação com a pressão do ambiente policial sobre a vontade dos acusados, a jurisprudência do STF sobre o tema, paradoxalmente, reforça o argumento de que a confissão na fase do inquérito policial não é apenas uma mera informação secundária. De fato, há decisões que validam e ampliam o uso dessas confissões pelo juiz:

"Habeas corpus": Fragilidade de provas da autoria: alegação de tortura: falta de prova. Depoimento de testemunha prestado na audiência sem a presença do réu. Deficiência do patrocínio da

pode intervir ou influir nas perguntas e nas respostas. CPP, art. 187. IV. H.C. indeferido.(HC 74198, Relator(a): Min. Carlos Velloso, Segunda Turma, julgado em 24/09/1996, DJ 06-12-1996). No mesmo sentido as decisões do STF: HC 73898, Relator(a): Min. Maurício Corrêa, Segunda Turma, julgado em 21/05/1996, DJ 16-08-1996; HC 69372, Relator(a): Min. Celso De Mello, Primeira Turma, julgado em 22/09/1992, DJ 07-05-1993; RE 136239, Relator(a): Min. Celso De Mello, Primeira Turma, julgado em 07/04/1992, DJ 14-08-1992. E as decisões do STJ: HC 188.527/GO, Rel. Ministro Gilson Dipp, quinta turma, julgado em 17/03/2011, DJe 04/04/2011; HC 139.412/ SC, Rel. Ministra Maria Thereza De Assis Moura, sexta turma, julgado em 09/02/2010, DJe 22/03/2010

“Art. 155, CPP. O juiz formará sua convicção pela livre apreciação da prova produzida em contraditório judicial, não podendo fundamentar sua decisão exclusivamente nos elementos informativos colhidos na investigação, ressalvadas as provas cautelares, não repetíveis e antecipadas". (Redação dada pela Lei $n^{0} 11.690$, de 2008). 
causa: inexistência para configurarem a anulação da decisão. 1 . Confissão do delito na fase do inquérito policial: se seguida da confissão, apura-se que na instrução da ação penal há elementos suficientes para a formação do convencimento do Juiz acerca da materialidade do delito, é desse e nesse conjunto probatório que se completa a prova. Alegação de tortura que em nenhum momento se provou não há como poder ser considerada: "o que não está nos autos, não está no mundo". (...) "Habeas Corpus" conhecido, mas indeferida a ordem. (HC 73565, Relator(a): Min. Maurício Corrêa, Segunda Turma, julgado em 10/06/1995, DJ 20-09-1996).

Como se depreende do trecho da decisão, a coação alegada pelo réu é ignorada porque ele, na qualidade de hipossuficiente diante do poder do Estado, deveria produzir prova contra seus eventuais torturadores. Logo, como ele não garantiu a prova de sua própria tortura, não poderá alegar que a confissão está viciada. Ademais, fora dos autos, o julgador parece desconhecer denúncias de violência policial no Brasil, razão pela qual a afirmação do réu somente poderia ser uma artimanha para enganar os juízes. Com base nesses pressupostos implícitos, observa-se que após a confissão na fase policial exige-se apenas que a instrução probatória processual complemente as declarações do acusado. Não se exige a mesma robustez probatória quando há confissão do réu, mesmo que tenha ocorrido sem respeito ao contraditório e à ampla defesa, o que enfraquece a condenação e prejudica o acusado.

As decisões que realçam o valor do Aviso de Miranda no caso brasileiro são paradoxais, pois são resolvidas nos termos da vetusta sistemática de nulidades presentes no Código de 1941 e anteriores à Constituição de 1988. É o que se depreende da seguinte ementa:

Recurso ordinário em habeas corpus. Constitucional. Processo penal. Falta de informação sobre direitos constitucionais. Irregularidade no laudo pericial. Nulidade da sentença. A falta de informação ao preso sobre seus direitos constitucionais gera nulidade dos atos praticados, se demonstrado prejuízo. Precedentes. Relatório médico preliminar não se confunde com laudo pericial decorrente de auto de exame de corpo de delito (CPP, art. 159/160). É no laudo que os dois peritos devem responder aos 
quesitos e firmá-lo. As nulidades ocorridas até o interrogatório judicial devem ser argüidas na defesa prévia. A não interposição do pedido de declaração da sentença caracteriza a preclusão da matéria omitida. Precedentes. Recurso desprovido. (RHC 79973, Relator(a): Min. Nelson Jobim, Segunda Turma, julgado em 23/05/2000, DJ 13-10-2000).

O relator afirmou ainda que a falta do aviso acarreta a nulidade dos atos praticados (RHC 79973, p. 423), mas a nulidade não foi reconhecida, pois se considerou que houve preclusão do pedido de declaração da nulidade, não tendo ocorrido efetivo prejuízo à defesa. A posição retomou o argumento utilizado pelo Ministro Sepúlveda Pertence de que a nulidade, mesmo absoluta, precisa causar dano para ser declarada, pelo princípio do pas de nullité sans grief. Segundo o Ministro Pertence "nem a nulidade absoluta, mesmo de fonte constitucional, pode fugir à exigência elementar da verificação de prejuízo" (HC 78708).

A necessidade de se detectar prejuízo à defesa para que a nulidade da prova obtida sem o Aviso de Miranda seja declarada não existia na jurisprudência norte-americana até a virada conservadora que propôs a desconstitucionalização da regra da exclusão da prova ilícita. ${ }^{26}$ Porém, o padrão das decisões dos tribunais superiores nacionais tem sido de desconsiderar a regra explícita da garantia constitucional. ${ }^{27}$ Isso significa, na prática, que em um país com tamanha violência institucional, o Poder Judiciário considera que direitos individuais para o conjunto da população abordada pela polícia são formalismos. Como demonstra a decisão de Miranda v. Arizona, é imprescindível que o Supremo Tribunal

26 A virada conservadora inicia-se com Calandra v. United States (1974), depois com Hudson v. Michigan (2006) e se consolida com Herring v. United States (2009). O principal argumento conservador é que a regra da exclusão não seria uma regra constitucional expressa e inerente ao devido processo legal. Tal argumento, no caso brasileiro, é insustentável, pois a exclusão da prova ilícita é norma constitucional. De igual modo, vinte anos depois de Miranda v. Arizona, Matthew Lippman (1986) já apontava decisões que tendiam a diminuir o impacto desse precedente.

27 No mesmo sentido a decisão do STF: RHC 107915, Relator(a): Min. Luiz Fux, Primeira Turma, julgado em 25/10/2011, DJe-217 Divulg 14-11-2011 Public 16-11-2011. E a do STJ: HC 66.298/PE, Rel. Ministro Felix Fischer, Quinta Turma, julgado em 04/09/2007, DJ 05/11/2007. 
Federal assuma uma posição proativa na luta contra a violência policial dos procedimentos de investigação.

Qual a razão para tamanha discrepância? Há um fato evidente que talvez sirva de resposta: os réus submetidos a interrogatórios nas ruas por policiais militares e nas delegacias por policiais civis, sem a presença de defensores, são na quase totalidade excluídos sociais.

Enfim, independentemente da posição quanto ao valor das informações ${ }^{28}$ colhidas no inquérito, resta evidente o peso negativo de declarações incriminadoras feitas pelo acusado durante um interrogatório policial fora dos padrões constitucionais.

Os argumentos apresentados na decisão de Miranda podem ser aplicados à solução de semelhantes conflitos doutrinários no Brasil. Ainda que a fase do inquérito policial seja, por natureza, mais simples que a processual, não se pode permitir o uso em desfavor do réu de informações obtidas sem o respeito efetivo ao direito ao silêncio. Qualquer declaração incriminadora obtida num interrogatório, antes mesmo da chegada à delegacia, que não respeitou os requisitos legais e constitucionais, teria, certamente, grande influência na decisão do juiz ou dos jurados, ainda que o acusado faça uso do direito ao silêncio na fase processual.

Nesse sentido, destaca-se a relação entre direito ao silêncio, proibição da incomunicabilidade do preso e garantia da assistência do advogado e da família ( $5^{\circ}$ LXIII e 136, § $3^{\circ}$, IV da CF; Convenção Americana de Direitos Humanos, art. $8^{\circ}$, n. 2, d) (SCARANCE FERNANDES, 2012, p. 270). Na prática jurídica brasileira, a proibição da incomunicabilidade é interpretada de modo formal ${ }^{29}$. Esse modo de entender o direito à assistência de um advogado acaba por servir apenas àqueles que, de

28 Se devem ser utilizadas apenas para conferir lastro mínimo para a propositura da denúncia, se são suficientes para a condenação de qualquer investigado, se devem ser confrontadas com outras provas e indícios, se podem ser opostas às provas colhidas na fase judicial, especialmente no caso de interrogatórios com versões distintas.

${ }_{29}$ Permite-se que o preso indique e fale com um advogado se possuir um, porém, no caso do hipossuficiente, as peças do auto de prisão e flagrante são enviadas à defensoria pública após a realização do auto de prisão em flagrante, ou seja, após o acusado ter assinado a confissão, sem a presença do advogado. 
fato, possuem condições econômicas suficientes para pagarem um advogado na fase do inquérito policial. Não tendo um advogado, o Estado não está obrigado a demonstrar, como está presente no Caso Miranda v. Arizona, que a confissão foi feita livremente. Por não existir esse ônus, as autoridades policiais também não demonstram qualquer preocupação com essa garantia.

O ciclo pouco virtuoso está estabelecido: se não há fiscalização obrigatória das confissões quanto a sua voluntariedade e espontaneidade, se as confissões são feitas sem a presença de um advogado, se as confissões serão utilizadas caso haja outros indícios, se a confissão negada na fase processual será confrontada com a obtida na fase policial - logo, a confissão transforma-se no principal caminho, senão o único, para a obtenção de provas, e, na busca desse caminho a violência policial se institucionaliza.

O debate no julgamento do Caso Miranda traz um alerta fundamental: a violência policial não se estabelece e se consolida apenas porque é uma prática institucional coorporativa interna aos órgãos de repressão. O Poder Judiciário tem um papel relevante na validação, ainda que pelo silêncio, das práticas de investigação utilizadas pela Polícia.

\section{Considerações Finais}

Nossa Corte Constitucional tem fechado os olhos para uma cultura institucional de violência e de desrespeito aos direitos individuais que está largamente documentada e presente nos noticiários cotidianos, nos documentos das organizações de Direitos Humanos, nos relatórios oficiais, nas comissões parlamentares e na literatura científica sobre o tema. Ao contrário da perspectiva adotada no Caso Miranda v. Arizona, o Supremo Tribunal Federal considera razoável inverter o ônus da regularidade da confissão para o acusado que foi custodiado e confessou sem a assistência de um advogado. Apesar da hipossuficiência evidente dos acusados, decorrente de sua submissão a uma polícia militarizada, de sua custódia numa delegacia, do grau de escolaridade e de exclusão econômica da maioria da clientela do sistema penal, exige-se que ele comprove o prejuízo decorrente da violação de um direito fundamental pelas instituições brasileiras. 
De outra parte, atribui-se muito valor às informações produzidas pelas confissões ou depoimentos obtidos na fase policial, e isso dá abertura a condenações infundadas. Se os elementos obtidos durante o inquérito não têm de seguir os requisitos processuais, previstos constitucionalmente, então não deveriam servir à delimitação da culpa ou como base para fundamentar a propositura da denúncia. Tais elementos necessitam ser valorados de acordo com a violação ou o respeito às garantias constitucionais do devido processo, devendo ser excluídos quando não respeitam os requisitos descritos em Miranda versus Arizona. Porém, não é isso o que se tem observado na construção jurisprudencial. ${ }^{30}$

Infelizmente, a jurisprudência do Supremo Tribunal Federal quanto ao respeito às garantias constitucionais dos suspeitos adota uma postura que corrobora inúmeras condenações obtidas com a violação à Dignidade Humana de grande parcela da população. Falta à nossa Corte Constitucional a preocupação pela Justiça que é oferecida, no cotidiano, às massas que são encarceradas. A ênfase no caso, no processo singular, não pode olvidar a importância da decisão em uma dimensão relevante do garantismo constitucional, a dimensão institucional da Justiça. De igual modo, a afirmação de que faltam provas para se concluir que o réu foi coagido em algum grau é, no mínimo, partidária. Partidária de uma cultura da violência e do desrespeito.

Por fim, como demonstra Miranda v. Arizona (384 U.S. 436, 1966), há soluções judiciais que podem ser adotadas. É necessário desautorizar as práticas de confissão forçada, exigindo-se as garantias mínimas na produção da confissão. Isso pode ser feito vencendo-se a interpretação de que a assistência do advogado somente deve ser materialmente garantida no interrogatório judicial. Ao invés disso, é preciso reconhecer que o direito ao silêncio não existe se o suspeito ou indiciado não está assistido por um defensor.

No caso brasileiro, a lei 13.245/2016 trouxe inovações, pois ampliou as prerrogativas de participação dos advogados nos inquéritos

30 Estamos de acordo com Aury Lopes Jr. e Ricardo Gloeckner, para quem: "O inquérito tem por finalidade o fornecimento de elementos para decidir entre o processo e o não processo, assim como servir de fundamento para as medidas endoprocessuais que se façam necessárias no seu curso" (2015, p. 222). 
policiais. Muito embora ainda não tenha introduzido a "investigação criminal defensiva" ${ }^{31}$, existente no sistema acusatório estadunidense, alterou o art. 7o da Lei $\mathrm{n}^{\circ}$ 8.906, de 4 de julho de 1994 (Estatuto da Ordem dos Advogados do Brasil), determinando a inclusão do inciso XXI -, segundo o qual é direito do advogado: "assistir a seus clientes investigados durante a apuração de infrações, sob pena de nulidade absoluta do respectivo interrogatório ou depoimento e, subsequentemente, de todos os elementos investigatórios e probatórios dele decorrentes ou derivados, direta ou indiretamente, podendo, inclusive, no curso da respectiva apuração.” Há, portanto, a nulidade do interrogatório quando ao advogado for negada a presença no interrogatório, conforme dispõe expressamente o referido artigo.

Por sua vez, a Resolução n 213/2015 do Conselho Nacional de Justiça estabeleceu que todo preso em flagrante deve ser levado à presença da autoridade judicial no prazo de 24 horas, para que esta avalie a legalidade e necessidade de manutenção da prisão. A referida Resolução impulsionou a judicialização mais célere do encarceramento preventivo, o que é apontado como uma medida para diminuição das arbitrariedades policiais.

Entretanto, nenhuma dessas medidas realiza plenamente o percurso do julgamento de Miranda v. Arizona, pois este provoca a exclusão de qualquer confissão (ou informação) obtida, por exemplo, por policiais nas ruas. Além do mais, em Miranda, a ilicitude e a consequente exclusão são provocadas pela violação dos direitos dos cidadãos. Logo, nesse caso a presença do advogado é retratada de modo instrumental à preservação do direito à não auto-incriminação, ao invés de ser considerado como um direito autônomo para a tutela das prerrogativas profissionais, como ocorre na lei $13.245 / 2016 .{ }^{32}$

31 Segundo Zanardi: “A investigação criminal defensiva pode ser entendida como a possibilidade da defesa participar da fase pré-processual, a fim de defender-se provando" (2016, p. 200).

32 A decisão em Miranda v. Arizona (384 U.S. 436, 1966) também não era suficiente para resolver todos os problemas referentes aos interrogatórios dos acusados. Como argumentam Elsen e Rosett, para haver mudanças efetivas nos padrões dos interrogatórios dos acusados seria imprescindível reformas nos registros, na forma e no tempo de prática desses atos, o que dependeria 
Miranda v. Arizona sugere que é possível desencorajar as práticas de confissão forçada, negando seu valor probatório, mas a partir de uma perspectiva sistêmica sobre o modo como a violência é produzida e tolerada. Isso somente pode ser feito vencendo-se a interpretação de que a falta do Aviso de Miranda e a falta da presença efetiva do defensor seriam nulidades sanáveis pela preclusão ou que dependeriam da demonstração de prejuízo. Ao invés disso, é preciso reconhecer a dimensão pública da violação desse direito individual, atribuindo o valor devido de prova ilícita e, desse modo, recusando o trabalho de investigação que não respeita os direitos fundamentais.

Esse caminho pode ser paralelo à reforma legislativa. Embora útil para pacificar o tema, a inserção de dispositivo legal explícito não é necessária. A interpretação constitucional, todavia, seria decisiva para introduzir exigências formais capazes de provocar a mudança dos padrões institucionais de garantia de direitos, pois obrigaria a presença dos advogados antes mesmo da lavratura do auto de prisão em flagrante.

Diante do exposto, retoma-se o problema delimitado na introdução deste artigo: confissões e depoimentos feitos diretamente aos policiais e sem a presença de um advogado podem ser considerados válidos? A admissibilidade das informações colhidas em interrogatórios nos quais o cidadão se defronta, sem assistência de um defensor, com o poder de fato das autoridades policiais, deve ser resolvido tendo em conta a hipossuficiência decorrente dessa situação fática ${ }^{33}$. Não há liberdade para exercer o direito à não autoincriminação quando o cidadão está, sob custódia, diante dessas autoridades. Portanto, cabe ao Estado garantir de maneira imediata a assistência jurídica ou aceitar o ônus de que confissões e/ou depoimentos feitos diretamente aos policiais, por

de mudanças institucionais e legislativas. Todavia, a decisão trouxe tema para o debate público, impondo a necessidade de mudanças (1967, p. 645-670).

33 Nesse sentido, a necessidade de máxima eficácia das garantias constitucionais, como aponta Aury Lopes Jr., precisa ser considerada como "limitação do poder e tutela do débil a ele submetido (réu, por evidente), cuja debilidade é estrutural (e estruturante do seu lugar)" (2012, p. 91). E, ainda que "no Processo Penal, forma é garantia e limite de poder, pois aqui se exerce o poder de punir em detrimento da liberdade." (LOPES JR., 2015, p. 23). 
cidadãos sob custódia e sem a assistência de um advogado, sejam considerados como prova ilícita e, por consequência, excluídos do processo para qualquer finalidade.

\section{Bibliografia}

BECKWHIT V. UNITED STATES, 425 U.S. 341, 1976. Disponível em: <http:// caselaw.findlaw.com/us-supreme-court/425/341.html>. Acesso em 28 dez. 2017. BOTTINO, Thiago. O Direito ao Silêncio na Jurisprudência do STF. Rio de Janeiro: Campus, 2009.

BOYD V. UNITED STATES, 1886. Disponível em: <http://caselaw.findlaw.com/ us-supreme-court/116/616.html>. Acesso em 29 dez. 2017.

BRANDÃO, Rodrigo. Diálogos constitucionais nos Estados Unidos e no Brasil. Revista Jurídica Luso Brasileira, a. 1, n. 4, p. 1443-1490, jan. 2015.

CARVALHO, Salo. Revisita à Desconstrução do Modelo Jurídico Inquisitorial. Revista da Associação Brasileira de Professores de Ciências Penais, v. 2, n. 2, p. 229-252, jan-jun 2005.

DUARTE, Evandro C. Piza, QUEIROZ, Marcos Vinícius Lustosa, GARCIA, Rafael de. A Rebelião da Prisão de Attica (Nova Iorque, 1971): opressão racial, encarceramento em massa e os deslocamentos da retórica da igualdade. In: MACHADO, Bruno Amaral; ZACKSESKI, Cristina; DUARTE, Evandro Piza (orgs). Criminologia e Cinema: narrativas sobre violência. São Paulo: Marcial Pons; Fundação Escola Superior do Ministério Público do Distrito Federal e Territórios, 2016.

ELSEN, Sheldon H.; ROSETT, Arthur. Protections for the Suspect under Miranda v. Arizona. Columbia Law Review, v. 67, n. 4, p. 645-670, 1967. https://doi. org/10.2307/1121083

ESCOBEDO v. ILLINOIS, 378 U.S. 478, 1964. Disponível em: <http://caselaw. lp.findlaw.com/scripts/getcase.pl?court=us\&vol=378\&invol=478>. Acesso em 19 set. 2017.

FARIA, Bento de. Código de Processo Penal. Rio de Janeiro: Record, 1960.

FRANCO, Ary Azevedo. Código de Processo Penal. Rio de Janeiro: Revista Forense, 1956. 
GRINOVER, Ada Pellegrini; GOMES FILHO, Antonio Magalhães; SCARANCE FERNANDES, Antonio. As Nulidades no Processo Penal. São Paulo: RT, 2010.

LEO, Richard A., e KOENIG, Alexa. Police Interrogation and Coercion in Domestic American History: Lessons for the War on Terror. In: NUSSBAUM, Martha and ANDERSON, Scott (eds.). Torture, Law and War: what are the moral and legal boundaries of the use of coercion in interrogation? Chicago: University of Chicago Press, 2010.

LEO, Richard A. The Third Degree and the Origins of Psychological Interrogation in the United States. In: LASSITER, Daniel (ed.). Interrogations, Confessions, and Entrapment. Kluwer Academic/Plenum Publishers, 2004. https://doi. org/10.1007/978-0-387-38598-3_3

LEWIS, Peter W. Criminal Procedure: the Supreme Court's view. St. Paul: West Publishing Co, 1979.

LIMA, Roberto Kant de. Cultura jurídica e práticas policiais: a tradição inquisitorial. Revista Brasileira de Ciências Sociais, v. 4, n. 10, p. 65-83, 1989.

LIPPMAN, Matthew. Miranda v. Arizona: Twenty Years Later. Criminal Justice Journal, v. 9, p. 241-290, jan. 1986.

LOPES JR, Aury. Direito Processual Penal e sua conformidade constitucional. 9a ed. São Paulo: Saraiva, 2012.

LOPES JR., Aury; GLOECKNER, Ricardo J. Investigação Preliminar no Processo Penal. $6^{\mathrm{a}}$ ed. São Paulo: Saraiva, 2015.

LOPES JR., Aury. Quando Cinderela terá suas próprias roupas? A necessária recusa à teoria geral do processo. Revista Brasileira de Direito Processual Penal, Porto Alegre, vol. 1, n. 1, p. 230-237, 2015. https://doi.org/10.22197/rbdpp.v1i1.13

MIRANDA V. ARIZONA, 384 U.S. 436, 1966. Disponível em: <http://caselaw. lp.findlaw.com/scripts/getcase.pl? navby $=$ case $\&$ court $=$ us $\& v o l=384 \&$ page $=436>$. Acesso em 19 set. 2017.

OREGON v. MATHIASON, 429 U.S. 492, 1977. Disponível em: <http://caselaw. findlaw.com/us-supreme-court/429/492.html>. Acesso em 19 set. 2017.

RILEY, Gail Blasser. Miranda v. Arizona: rights of the accused. Berkeley Heights: Enslow Publishers, 1994.

SCARANCE FERNANDES, Antônio. A Mudança no Tratamento do Interrogatório. Boletim IBCCRIM, ano 17, n 200, 2009. 
SCARANCE FERNANDES, Antônio. Processo Penal Constitucional. São Paulo: RT, 2012.

SONGER, Donald R.: SHEEHAN, Reginald S. Supreme Court Impact on Compliance and Outcomes: Miranda and New York Times in the United States Court of Appeals. The Western Political Quarterly, Vol. 43, No. 2, 1990, p. 297-316. https:// doi.org/10.1177/106591299004300206

TROIS NETO, Paulo Mário Canabarro. Direito à não autoincriminação e direito ao silêncio. Porto Alegre: Livraria do Advogado, 2011.

WANDERLEY, Gisela Aguiar. Liberdade e Suspeição no Estado de Direito: o poder policial de abordar e revistar e o controle judicial de validade da busca pessoal. Dissertação (Mestrado em Direito) - Universidade de Brasília, Brasília, 2017.

WANDERLEY, Gisela Aguiar. A busca pessoal no direito brasileiro: medida processual probatória ou medida de polícia preventiva? Revista Brasileira de Direito Processual Penal, Porto Alegre, v. 3, n. 3, p. 1117-1154, set. 2017. https://doi. org/10.22197/rbdpp.v3i3.96

ZANARDI, Tatiane Imai. Investigação Criminal Defensiva: uma prática a ser difundida. Revista Justiça e Sistema Criminal, v. 8, n. 14, p. 191-216, 2016. 


\section{Informações adicionais e declarações dos autores (integridade científica)}

Agradecimentos (acknowledgement): Agradecemos a João Victor Martins pela revisão de forma no texto final.

Declaração de conflito de interesses (conflict of interest declaration): os autores confirmam que não há conflitos de interesse na realização das pesquisas expostas e na redação deste artigo.

Declaração de coautoria e especificação das contribuições (declaration of authorship): todas e somente as pessoas que atendem os requisitos de autoria deste artigo estão listadas como autores; todos os coautores se responsabilizam integralmente por este trabalho em sua totalidade.

- Gabriela Ponte Carvalho: projeto e esboço inicial, coleta e análise de dados, levantamento bibliográfico, revisão bibliográfica, redação, revisão crítica com contribuições substanciais, aprovação da versão final.

- Evandro Piza Duarte: projeto e esboço inicial, levantamento bibliográfico, revisão bibliográfica, redação, revisão crítica com contribuições substanciais, aprovação da versão final.

Declaração de ineditismo e originalidade (declaration of originality): os autores asseguram que o texto aqui publicado não foi divulgado anteriormente em outro meio e que futura republicação somente se realizará com a indicação expressa da referência desta publicação original; também atestam que não há plágio de terceiros ou autoplágio. O presente texto foi motivado pelas pesquisas efetuadas em decorrência do Projeto UnB/Direito, “Quem é o Suspeito do Crime de Tráfico de Drogas: A dinâmica e influência dos preconceitos raciais e sociais na identificação e definição das condutas de usuário e traficante de drogas pela polícia”, selecionada no âmbito do Edital $\mathrm{n}^{\circ}$ 01/2012 do projeto Pensando a Segurança Pública, lançado pela Secretaria Nacional de Segurança Pública do Ministério da Justiça - SENASP e pelo Programa das Nações Unidas para o Desenvolvimento - PNUD, o qual resultou nas atividades de pesquisa para elaboração da monografia apresentada à Faculdade de Direito da Universidade de Brasília, como requisito parcial para obtenção do grau de bacharel em Direito de Gabriela Ponte Carvalho. 
Dados do processo editorial

(http://www.ibraspp.com.br/revista/index.php/RBDPP/about/editorialPolicies)

- Recebido em: 25/09/2017

Equipe editorial envolvida

- Controle preliminar e verificação de plágio: 17/10/2017

- Avaliação 1: 31/10/2017

- Editor-chefe: 1 (VGV)

- Revisores: 3

- Avaliação 2: 03/11/2017

- Avaliação 3: 12/11/2017

- Decisão editorial preliminar: 14/11/2017

- Retorno rodada de correções 1: 30/12/2017

- Decisão editorial preliminar 2: 14/01/2018

- Retorno rodada de correções 2: 09/02/2018

- Decisão editorial final: 16/02/2018

\section{COMO CITAR ESTE ARTIGO:}

CARVALHO, Gabriela Ponte; DUARTE, Evandro Piza. As Abordagens Policiais e o Caso Miranda v. Arizona (1966): violência institucional e o papel das cortes constitucionais na garantia da assistência do defensor na fase policial. Revista Brasileira de Direito Processual Penal, Porto Alegre, vol. 4, n. 1, p. 303-334, jan./ abr. 2018. https://doi.org/10.22197/rbdpp.v4i1.109

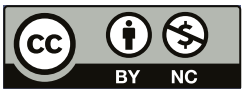

Esta obra está licenciada com uma Licença Creative Commons Atribuição-NãoComercial 4.0 Internacional. 